Article

\title{
Safety Work with an Ethnic Slant
}

\author{
David Wästerfors * and Veronika Burcar \\ Department of Sociology, Lund University, 22100 Lund, Sweden; E-Mails: David.Wasterfors@soc.lu.se (D.W.), \\ veronika.burcar@soc.lu.se (V.B.); Tel.: +46-222-8203 (D.W.) \\ * Corresponding author
}

Submitted: 8 November 2013 | In Revised Form: 12 May 2014 | Accepted: 21 May 2014 |

Published: 17 September 2014

\begin{abstract}
Ethnic discrimination in the criminal justice system is a well-researched topic, but the significance of ethnicity in policing activities at more mundane levels has attracted less attention. This article analyzes ethnographic data on municipal 'safety work' in a Swedish city troubled with robberies, vandalism, and violence. It shows how the efforts of different safety workers, operating to curb crime and promote security, came to focus on the 'soft' policing of young men with various immigrant backgrounds. A set of street-level safety practices, performed within spatial demarcations, was found to represent a more-or-less silent orientation towards local minorities; a focus on non-Swedish ethnicities was embedded in the policing activity. This article points out the importance of implied ethnicities in the contemporary landscape of plural policing.
\end{abstract}

\section{Keywords}

crime; ethnicity; media; plural policing; safety work; security; urban space

\section{Issue}

This article is part of the special issue "Policing Ethnicity: Between the Rhetoric of Inclusion and the Practices and Policies of Exclusion", edited by Professor Abby Peterson (University of Gothenburg, Sweden) and Professor Malin Åkerström (University of Lund, Sweden).

(C) 2014 by the authors; licensee Cogitatio (Lisbon, Portugal). This article is licensed under a Creative Commons Attribution 4.0 International License (CC BY).

\section{Introduction}

Contemporary public security is not exclusively a task for the police. The fact that a plethora of public, commercial, and voluntary agencies aim to protect people and property (Loader, 1997, p. 377) has given rise to issues regarding 'plural policing' (Loader, 2000; Jones \& Newburn, 2006) or an 'extended police family' (Crawford, 1997). The criminological interest in ethnic minorities, their statistical over-representation in arrests and prisons (Tonry, 1996; Bosworth, 2004), and the ethnically discriminatory mechanisms within the criminal justice system (Ekman, 1999; Granér, 2004; Pettersson, 2005; Diesen, 2006) have attracted attention to the policing of ethnic minorities. It is not always clear whether ethnic minorities should be seen as categories that are substantially more involved in crime than others or as categories that are discriminated against by the police and the justice process, or both. In any case, the policing of various ethnic groups has turned into a burning issue.

In this context it is relatively unknown by what mechanism more mundane police activities can subtly draw on ethnicity as a tool in control interactions. What social circumstances make mundane policing practices ethnically oriented? When analyzing policing practices, ethnicity is typically treated as an abstract category; therefore, we should ask how it could become similarly relevant as a more everyday, interactional accomplishment.

This article aims to specify the practices through which non-governmental policing may come to involve and reproduce an underlying orientation toward ethnic minorities through a set of spatially demarcated streetlevel interactions. In doing this, we intend to show that 
policing practices do not need to be either ethnically neutral or intentionally discriminatory. Ethnicity can also become relevant implicitly, by way of circumstances and recurrent interactional events. Detailed data on individual interactions, accounts, and contexts are required to detect these processes; discursive or structural analyses are insufficient.

This study draws on ethnographic data from a case of municipal safety work in Landskrona, a small Swedish city with relatively high frequencies of robbery, vandalism, violence, and ethnic tension. Although the municipality focused its safety work on a specific downtown area, the context encountered and the responses that were implemented turned the focus toward young male immigrants. This case demonstrates how 'policing', in a broad but downplayed sense (not carried out by the police, but by various 'city patrollers') can be designed, delimited, and accomplished in such a way that ethnic minorities implicitly become its major concern. The case also shows how local crime news can sustain these processes by providing a symbolic context, where the major population sector (Swedes) is typified as victims, and immigrants are typified as perpetrators. The context described by the local media created heightened sensitivity, which sometimes made it difficult for safety workers to openly speak about ethnicities (some articles were perceived as portraying attitudes on the verge of racism), but the context also made it necessary for safety workers to make ethnic references.

Ethnicity typically proved to be an unspoken or 'half spoken' matter in our data. Instructions for safety workers did not include phrases like 'keep a special eye on immigrants', and the corrections safety workers imposed on youth in the street did not seem to include overt racial discrimination. Instead, as a whole, the project was impregnated with ethnically-oriented concerns, due to the particular areas under surveillance, the safety workers' everyday interactions with each other and with youth, and through the rhetorical motivation of the local press. Safety workers' ways of constructing knowledge, their use of 'talks' in the street as a control strategy, their visibility in downtown Landskrona, and their efforts to keep youth conventionally 'active' were subtly underpinned by ethnic considerations and simultaneously reproduced some ethnic categories.

Several of our findings are consistent with those of other studies, particularly regarding the disciplinary functions of youth work and policing. Ilan (2010) uses ethnographic data in a youth justice project in Dublin to show how youth workers propagated certain idealized behavioral expectations towards youth that were normally regarded "at risk"; for instance, youth behavior in indoor and outdoor leisure activities. In that study, the youth workers' "pedagogic intervention" was meant to transform youth, but they disregarded the fact that engaging in an offense may be a "creative and viscerally satisfying response to the marginality generated by the confluence of their biographies, class, gender, and youth" (Ilan, 2010, p. 37). Ilan points out that youth resistance may very well represent a refusal to acquiesce to pedagogy in general, which laid the ground for social tensions. In Landskrona, an equivalent pedagogic intervention is recognizable in the safety workers' efforts to "motivate" street youth. However, we would like to add that, although tension was expected when trying to convince youths to exchange the street style of "doing nothing" for the conventional activities suggested by the safety workers, it was hoped that a bridge could be formed by identification with some of the safety workers that had immigrant backgrounds. Thus, here, shared ethnicities are given a special, crime-preventive meaning. Hansen Löfstrand (2013, p. 233) found a similar meaning in her study on a private security company in Sweden, aiming at ethnic diversity (mångfald, in Swedish); it was considered a great advantage to hire guards with another ethnic background than a Swedish one when working in Swedish suburbs. The idea is that staff 'differences' match the 'differences' in the field, so that efforts to enforce discipline are made easier. The chances of 'ethnic matching' in work encounters turned greater, and if the guard was the one that invoked an ethnic identification (rather than the youth) it was defined as helpful in producing safety, Hansen Löfstrand (2013, pp. 245-246) argues.

Standard police work also tries to enforce social discipline (Choongh, 1998). In fact, one of the "core police functions" in the 19th and 20th centuries has been to intervene against the "dangerous" element of the lower classes (McAra \& McVie, 2005, pp. 6-7). Currently, males that have an active "street life" and a lowerclass or less-affluent background are generally overpoliced, and consequently they are particularly targeted for discipline. In an analysis of self-report data from youth in Edinburgh, McAra and McVie (2005) showed that "unrespectable" street life was the normal focus of the police. Once identified as a trouble-maker, a youth appeared to be "sucked into a spiral of amplified [police] contact" (McAra \& McVie, 2005, p. 9), regardless of whether they continued to commit criminal offenses; thus, the police contributes to the perpetration of the very behavior they are trying to contain. Previous police contact proved to be the most powerful predictor of later adversarial contact in McAra and McVie's study.

With the Landskrona data, we may argue that policing tended to recreate a certain category of "usual suspects", but the difference between this study and previous studies is that we are investigating preventive work that use a much "softer" approach than "adversarial police contact". Safety workers in Landskrona seldom act as confrontational as the police, and when a serious confrontation emerges, their responsibility is 
to call (rather than replace) the police. Also we highlight ethnicity rather than class, and we are doing so not in terms of a statistical category, but in terms of an active accomplishment in social interactions. So-called ethnic profiling may be included in a patrolling policemen's 'silent knowledge' and activated through spatial demarcations, such as immigrant-dominated suburbs (Östlund, 2013, p. 119), and a similar but implicit 'profiling' seem to exists in the case of safety work. Here, though, we are inspired by ethnomethodology as an analytic approach to ethnographic data (Pollner \& Emerson, 2001, p. 125; cf. Garfinkel, 1999; Heritage, 1984). We employ this approach to capture how ethnicities can be interactionally produced and sustained in the "soft" versions of policing. Ethnicity is considered a continuous social construction, an aspect of social relations (Eriksen, 2004) that is continuously created and recreated, in this case by safety workers.

But despite the fact that we do not understand ethnicity as 'an element in the world' but as 'a way of seeing the world' (Brubaker, Loveman, \& Stamatov, 2004, p. 47), we cannot avoid "doing" ethnicities ourselves, as analysts. We inevitably risk reproducing ethnic categorizations the moment we start describing them; for instance, when we use the terms "Swedes", "Albanians", "Turks", "immigrants", "immigrant background", "minorities", etc., we are recreating an ethnicity with each label.

The situation in this study is equivalent to that of Becker in his study of marijuana smokers: he felt that he had to use the term "marijuana smokers", despite the fact that he was interested in how actors (interactively and interpretatively) became marijuana smokers by engaging in certain activities. Similar to Becker (1998, pp. 44-46), we treat ethnic categories not as specific kinds of people, but as activities (for instance the activity of calling something Bosnian, Turkish or Swedish, implying a shared ethnicity or using a certain language, describing people in ethnic terms, etc.). Nevertheless, we do use categories now and then, in Becker's way: as a kind of descriptive shorthand.

\section{Settings and Methods}

This study began when the local official in charge of organizing crime prevention in Landskrona asked us to write a report on their latest project, 'A Safe Downtown'. The purpose was to collect data on this project as a whole and to describe how it had unfolded. We used ethnographic methods to understand the project's social practices and to capture the local opinion in Landskrona.

\subsection{Landskrona and Its 'Unsafe' City Center}

Landskrona's official safety work stemmed from the efforts of local politicians to deal with 'the youth prob- lem' in the downtown area, which started in 2005. The number of reported assaults and robberies involving young men, as both perpetrators and victims, was increasing at that time, and according to municipal surveys, many citizens felt insecure in the streets and in public places. In 2004 , over $20 \%$ of respondents said that they had abstained from an activity (going to the movies, engaging in sport activities, etc.) due to perceived insecurity (Polisen 2004). Around 54\% of reported assaults in Landskrona were located within the so-called 'critical area', a triangle identified by the police in the central and eastern district, which included shops, pubs, squares, pedestrian walkways, schools, parks, parking lots, and sight-seeing spots (Kriminalunderrättelsetjänsten 2006).

In response to the perceived insecurity, local authorities launched a variety of efforts to curb crime. First, they recruited security guards, called 'yellow jackets' (until they changed uniform), and gave them extensive authority. These guards act under the oftenmentioned Paragraph 3 in the Swedish law on security guards, which states that they can patrol a generous triangle of the city center; i.e., they are not limited to standing outside pubs and clubs or supervising specific public events. Also, two variants of 'safety workers' were employed to patrol the city center; the 'blue jackets', who belong to the local municipal crime prevention crew, and the 'red jackets', who belong to the local social services. The security guards and the red jackets work evenings and weekend nights; the blue jackets walk the city on weekday afternoons and evenings. All these safety workers act under different formal conditions; e.g., the security guards have power to intervene; the red jackets work outreach (i.e., making contact and offering encouragement and support); and the blue jackets serve as adult role models or 'city hosts' (serving as assets in the city, cooperating with shop assistants and communicating with youth). However, in practice, these three types of workers often share and describe the same approach.

Additional crime prevention strategies include offering youth in Landskrona a cell phone registry, where stolen phones could be disabled by a phone call from the rightful owner; some street sections were closed to curb a black market taxi business; and social efforts were directed toward youth deemed 'troublesome' and potentially criminal. Some years prior, camera surveillance was installed in and around a popular parking lot within the critical area (Wästerfors (2006) conducted a separate study on the cameras). In other words, the new safety work was implemented in addition to other related crime preventive efforts.

The blue jackets occasionally visit places outside central Landskrona; for instance, the railway station and, during summer, the neighborhood of Borstahusen, a camping area, and the beaches. However, the patrols of all the safety workers are focused on the 
downtown area. Many other Swedish cities have a high proportion of residents with an immigrant background in the suburbs, but in Landskrona, many immigrants live in the central parts of the city. Currently, around $20 \%$ of Landskrona's 42,000 inhabitants live in the administrative district studied (called 'Centrum och Öster' or Central-Eastern), and $42 \%$ of these inhabitants have a 'foreign background' (Centrum- och Österlyftet. Strategisk stadsdelsplan 2007, p. 5). In a tabloid, a local official gave an account for this: "in Landskrona, those who can afford it get out of the city center as soon as they can, but in other cities, it is usually the other way around" (Olsson 2007). Officials involved in 'safety work' told us that these circumstances made it difficult to compare their work with other crime prevention projects in other cities or areas; for instance, in suburbs stigmatized by "ghetto" areas located on the outskirts of large cities. They felt that Landskrona required a special kind of presentation in inter-municipal meetings and collaborations. In that sense, Landskrona might be considered a mini-version of Burgess's model of a city from the Chicago school in the 1920s; it has high-priced residential areas in the 'outer zones' and a socially 'disorganized' zone in transition in the center (Lilly, Cullen, \& Ball, 2007, p. 37; Burgess, 1967, p. 55). At night, the downtown area do not primarily feature adult, middle-class Swedes going to clubs, theatres, or restaurants, as would be common in many other Swedish towns of similar size. Instead, the area is populated by youth, who gather outside schools or pubs, within and outside an Internet café, next to a youth recreation club, on benches, in squares, around schools, etc. Many are immigrants or children of immigrants; they describe themselves in this way and other people involved in our study use the same terminology; for example, they are referred to as Kosovo-Albanians, Turks, Croats, Bosnians, Arabs, etc., even though they may simultaneously feel and call themselves Swedes.

When the 'Safe Downtown' project started, local officials employed eight people to become blue jackets (the municipal city wanderers), and it was no coincidence that all eight had immigrant backgrounds. This ethnic mix guaranteed a 'broad language competence', claimed the organizer, implicitly referring to those that were targeted for control; youth of non-Swedish ethnicity (cf. Löfstrand, 2013). The organizer and her closest colleagues, however, were Swedes. One of the arguments for evaluating the project was that the crime trends in Landskrona had elements of what the police called 'Europeanized crime', a description that implied foreign, relatively severe, and somewhat 'un-Swedish' crimes.

Alongside the intensified safety efforts, crime was a recurring theme in the local press. This was not particularly remarkable, until it was put into perspective; compared to the nearby, larger town Helsingborg, Landskrona was much more frequently mentioned in crime associated reports in the local media (Burcar and Wästerfors, 2007). When discussed in the national media, Landskrona is still repeatedly associated with crime and insecurity.

Landskrona as a whole is also distinguished for its relatively strong support of Sverigedemokraterna ('The Sweden Democrats'), a nationalist party that stands against 'mass immigration'; this party often rhetorically link immigrants to criminality and social problems. In the election of 2006, the party received one fifth of the votes of Landskrona (in the next election of 2010, the party lost some of its support). This party affiliation attracted a lot of attention in Sweden. National media tended to report on Landskrona for its criminality, ethnic tensions, and youth problems, and now the city was also associated with an extremist party. In Växjö, another small city in southern Sweden, a local politician said 'We do not want to become like Landskrona in a couple of years', when referring to a series of news reports in the local papers Smålandsposten and Landskronaposten in 2007. Feelings of an insecure city center most likely contributed to the strong support for Sverigedemokraterna in Landskrona. ${ }^{1}$

\subsection{Methods}

First, we organized 'go-alongs' (Kusenbach, 2003), where we followed security guards, workers known as 'red jackets', and workers known as 'blue jackets' to get a picture of their work and its practicalities. During the go-alongs, we performed field-based interviews (Emerson, Fretz, \& Shaw, 1995) with safety workers and the local people they met. Second, we conducted field-based interviews with social workers, leisure workers, policemen, security guards, shop owners and their assistants, youth, and 'people in the street'. Third, we visited a locally, well-known youth club, called Nova, in downtown Landskrona and two schools, where we conducted focus group interviews with four girls and two boys aged 15. Fourth, we studied statistics

\footnotetext{
${ }^{1}$ The impact of the local media on fear and its part in the party's success were much debated, both locally and nationally. On the radio program 'Vår grundade mening' ('Our grounded meaning') (Sveriges radio P1 2006-10-26; also Sveriges radio Ekot 2009-09-24), the host invited people living in Landskrona, media researchers, police, and representatives from the local newspaper, Landskronaposten, to discuss news articles about gangs in Landskrona and what impact they had on the party's success in the election. In an article published in Landskrona Posten/Helsingborgs Dagblad (2006-11-12), the media researcher Ylva Brune discussed 'The paper, the juvenile gangs, and the opinion'. Brune said 'I would say that the newspaper has made an important contribution in creating a right-populist climate of opinion, not only by a special kind of news coverage, but also by actively orchestrating an opinion that advocates enforcing a get-tough police' (Ibid., our translation).
} 
from the police and the Swedish National Council for Crime Prevention, and additionally, we studied local newspaper articles on crime and safety. ${ }^{2}$ We could quite easily contact people through our networks and knowledge from a previous study on camera surveillance in a central parking place in Landskrona (Wästerfors 2006).

To talk to people in the street, various professionals, and safety workers provided insights into the symbolic context that became the frame of reference for the crime prevention project. Newspaper articles also added to our understanding of this context; in the news and in informal talks, immigrants were mentioned more often than in conversations with officials. Although we could localize this context to downtown Landskrona, we could not identify it with a particular setting, organization, or group. Rather, the local reception of the unfolding safety work in Landskrona was talked about in various places and in various social settings. Because one of us (Veronika Burcar) lived in downtown Landskrona at the time, it was easy to follow the daily discourse. These circumstances prompted us to shift sites repeatedly, and engage in a broad variety of situations and gatherings. Thus, our material is not ethnographic in the classic sense, which requires a careful portrayal of a single setting or culture and its members. Rather, this material provides glimpses of several settings and diverse sets of members. The ethnographic purpose of this study lay in our aim to describe how the local safety work came to be implemented and to portray those involved in it.

We personally heard people invoke ethnicities when referring to Landskrona in general, and crime prevention in particular. At a youth club, Nova, boys and girls greeted us by quickly asking whether we were 'svenne' or 'blatte', colloquial expressions for 'Swede' and 'immigrant' typically used by youth. The blue jackets that had immigrant backgrounds also asked us about our backgrounds, but in a more adult way (after some time) and with more polite expressions (e.g., 'where are you from?'). We gradually learned that, although the safety work was focused on an urban area (downtown Landskrona), people sometimes interpret-

\footnotetext{
2 We gathered most of the qualitative data from the summer of 2006 to the spring of 2007. In sum, this original material included: four 'go-alongs' with safety workers; a set of fieldbased interviews with social workers, leisure workers, policemen, youth, and shop and pub employees or owners; visits to the youth club Nova; two focus group interviews with four girls and two boys at Gustav Adolfsskolan and Dammhagskolan (two schools); two interviews with representatives of the police and social services in Landskrona; 24 interviews with people working in downtown Landskrona; 19 short interviews with people in the street. In 2014, David Wästerfors performed more field-based interviews with safety workers and an additional 'go-along', to gather sufficient data to finalize this article.
}

ed it in terms of a focus on ethnicity. During a city walk, one of the blue jackets described how some young individuals had indicated that they felt 'singled out as immigrants' because only immigrants wore blue jackets. That safety worker also questioned this arrangement, and wished that non-immigrants would be included in the work group to discourage the impression that immigrants were selected to control other immigrants.

We also learned that people saw local media as significant; several times during our fieldwork, we were asked whether we were local reporters, a profession that did not seem popular among the ethnically-mixed blue jackets and youth in downtown Landskrona. Some blue jackets said that reporters 'campaigned against' immigrants, that their articles lacked 'hard facts', and that repeated reports on immigrant crimes had supported the nationalist party Sverigedemokraterna. Michail (one of the blue jackets) was indignant about a journalist who made Landskrona look "too divided" by highly contrasting opinions in the local newspaper (Landskrona Posten). "That journalist incites antiimmigration", said Michail. He argued that an Albanian man, depicted by a journalist in an article about 'the violence in his blood', did not exist in reality.

Our learning process was probably facilitated by the use of loosely-structured interviews and our interest in informal talks and 'go-alongs'. One might even say that the process was generated by our ethnographic method, because people's tendency to associate crime and crime prevention in Landskrona with young men of immigrant backgrounds was typical of informal interactions. An ethnographic approach made it possible to detect and address 'implicit ethnicities' in a more down-to-earth manner than would have been possible with, for instance, structured interviews or questionnaires.

\section{Implied Ethnicities in Policing Downtown Landskrona}

\subsection{Subtle Concerns in Intelligence Gathering}

One of the safety workers' methods consisted of constructing knowledge about youth activity in downtown Landskrona. The blue jackets and red jackets continually exchanged information with each other and with the security guards concerning the city's youth-where they could be found on a particular day or night, their purpose, their companions, and how long they might stay there. For instance, safety workers might discuss a big party or club, where boys and girls were expected to gather; they might discuss whether a particular place (a school yard, a square, a café) would continue to attract a fair amount of people on a given Friday or Saturday night, and whether they should continue surveillance there. Some safety workers communicated 
this information to colleagues, even when they were not on duty, to let them "know roughly where the kids are', as one of the red jackets put it.

We start our city walk. One of the 'red jackets' says that you have to love this work (to be able to do it), but a colleague interrupts and starts explaining what areas need to be checked extra carefully this night. The colleague seems a little stressed out. Apparently, there will be a wedding party at the People's House and some kind of 'fire show' outside Madde's Café and Restaurant, in addition to other events. Because this will attract a lot of people, the safety workers argue, these places must be carefully watched. (fieldnotes)

Typically, safety workers go to what Goffman (1967, p. 149) calls 'where the action is': in the excerpt above, a wedding party, a fire show (artists playing with fire and fireworks), and other expected gatherings. Where there is 'action', there are individuals that take chances and display their character; this type of situation, as Peterson argues, concerning policemen and criminal youth (2008, pp. 114-115), is attractive for both supporters and disrupters of social order. Safety workers aim to follow youth in their local endeavors to find fun, exciting spots in Landskrona's urban area, to ensure that 'safety' could be upheld where they assume it can be challenged. When the streets happened to be relatively empty one night, they explained this in terms of their previously constructed youth knowledge. For instance, when nobody seemed to be hanging out at the local DVD and Video rental shop (Videomix) one night, one of the blue jackets told us that there was a Bosnian event going on in nearby Helsingborg: 'Everybody's probably there.'

The latter example is indicative of how ethnicities were implied within this intelligence gathering. Safety workers did not explicitly say that their main object was to watch young men with immigrant backgrounds; however, the things they mentioned and the wording they used during our 'go-alongs' - a Bosnian party, an Albanian party, a wedding party, a set of schools with a high proportion of immigrants-made it clear that this was the object. Knowing the whereabouts of youth with an ethnic background other than Swedish turned out to be a central task, because this category dominated the downtown area assigned to the safety workers. When, as in this example, Bosnian or Albanian festivities were taking place elsewhere, the safety workers' area became a bit empty, and their tasks were consequently less demanding; they assumed that 'everybody' would probably be there.

A similar logic was implied in a campaign against young people's careless use of fireworks (for instance around Christmas and New Year's Eve), which had caused some turbulence and injuries in downtown
Landskrona. In that case, the blue jackets turned to the local classrooms that taught Swedish for Immigrants (SFI). The principal of the school gave the schedule to the blue jackets, and they were given time during language lessons to inform the students about the dangers of their kids using fireworks in the streets; simultaneously, they gathered information about the parents' attitudes. "There were three of us", one of the blue jackets explained, "to cover several languages: Albanian, Arabic, Bosnian..."

As we sit in the blue jacket's office and talk about the fireworks information campaign, I (David, one of the researchers) ask "Why SFI?" One of the blue jackets raises his eyebrows and says "we know that they are there"; that is where the parents "spend their days". He goes on proudly describing the procedure: two days, three blue jackets, and 20 groups of SFI students. Later, when I talk with another bluejacket on the same topic, he responds that also the local Islamic association was informed and the mosque. When I ask how the "Swedish parents" got the fireworks information, they respond that they just sent a brochure through ordinary mail. (fieldnotes)

Such instances indicate how an interest in ethnically defined concerns and attitudes were subtly implicated in safety workers' intelligence gathering. In the blue jacket's answer "we know that they are there", 'they' denotes the parents of troublesome kids, and "they" can be found at courses for SFI. Underlying ethnic orientations made the choice of addressing SFI courses seem reasonable.

If we consider ethnicity as a practical, interactional accomplishment (Moerman, 1974; Pollner \& Emerson, 2001, 2010, p. 125), ethnographers must look for actual occasions of ethnic identification, rather than merely presuming ethnic categories or characteristics. Thus, rather than treating ethnicity as a fixed attribute, it turns more fruitful to treat it as an ongoing accomplishment of local practices (Moerman, 1974). However, in this case, the accomplishment of ethnicities did not consist of safety workers explicitly saying "our main troublemakers are at their Bosnian festivity", or "this Albanian wedding will be a place for quarrels", or "all these kids with immigrant parents must stop using fireworks in the streets"; instead, they pointed out indirectly that those events and circumstances are highly relevant, because they facilitated situations or people that were associated with potential disruptions of social order; and consequently, this was something they should include in their safety work. Thus, the practice and object of intelligence operations were discreetly or indirectly clothed in ethnic terms.

There are two possible counter-arguments to our explanations. First, one could say that implicating eth- 
nicity in the above sense is insignificant and banal, given the diverse population in Landskrona. To ignore ethnicity might lead to ignoring the specific needs and characteristics of the respective groups. Second, if one could argue that implicit ethnic profiling were as significant as we suggest, what would stop safety workers from explicitly implicating ethnicity to a greater extent? They could, after all, have talked and acted more directly and openly about ethnic groups and differences.

Our data as a whole, however, argue against these objections. It is true that safety workers' practices of implicating ethnicity typically revolved around banal events and circumstances, but this does not necessarily make them irrelevant (cf. Billig, 1995, on banal nationalism). Basically, intelligence gathering could have been shaped according to Swedish festivities or typical meeting points for youths with a Swedish background, or the orientation of the work could have been expressed in non-ethnic terms. Moreover, the safety work as a whole could have been defined and delimited in other ways, including or focusing on typical 'Swedish' events or housing areas. It is noteworthy that safety workers never seemed to talk about a Swedish party in the same ways they talked about Bosnian or Albanian festivities; the Landskrona majority was simply not ethnicized.

To address the second point mentioned above, one argument is that ethnic attitudes could have been expressed more explicitly and dealt with more openly, but the terminology was influenced by the symbolic context provided by the local media and Sverigedemokraterna. For instance, in interviews with policemen and other officials connected to the 'Safe Downtown' project, if we asked about immigrants in a more overt way, such as: is it true that 'immigrant kids' often make trouble in the center?, our words were immediately associated with the contemporary, quite outspoken local journalists, which the interviewees referred to and often complained about.

Safety workers, in addition to the people we met in downtown Landskrona, often regretted that immigrants and ethnically defined "gangs" had been identified in the local newspaper; they pointed out that the journalists had exaggerated, dramatized, polarized, and contributed to hostility against immigrants or a racist atmosphere. A series of four articles about immigrant "youth gangs", published in the local Landskronaposten in March 2006, particularly caught the attention of many field-members, and those we met during our fieldwork referred to them frequently. For instance, a man called 'Anders' (a common Swedish name) explained why he and others were victimized: 'Because we are Swedes-reverse racism is what it is...' Victims were said to be called 'Swedish bastards' ('svennejävel') in downtown Landskrona, and Swedish victims were said to sometimes believe that 'all immigrants are criminals'.

This environment meant that publicly speaking about safety work in ethnic terms was associated with a deplorable development in the local media; thus, it was not always possible to talk explicitly about ethnicities without simultaneously referring to and regretting local news reports. In that sense, the symbolic context provided by journalists became an obstacle that barred open references to ethnicities. However, at the same time, this context influenced the entire safety project by providing an account for its directive toward troublesome ethnic minorities. The media also motivated people to discuss these issues and it became a resource in conversations. The participants in the study constantly seemed almost obliged to comment on the local news coverage.

Youth, on the other hand, can speak more openly, but also in a more easy-going way; they talk about 'svennar' and 'blattar' (Swedes and immigrants) as two distinct groups, and they sometimes also use these words as adjectives ("svennigt", "blatte-") when mentioning gatherings and events, telling jokes and anecdotes, describing themselves, etc. This style of talking is not commonplace among safety workers, who treated ethnically-loaded categories more indirectly.

Intelligence gathering could also manifest itself in fairly precise terms, like knowledge of particular individuals. Safety workers were proud to be familiar with the names and faces of individuals. "You recognize the kids", one of the blue jackets said, "and most of them respect us." "Even though you cannot remember all of them", he continued, "you know them 'as figures' in the street", which meant that he was able to identify their faces and behavior.

Blue jackets greet a lot of people, identify them, and chat with them. Sometimes they exchange greetings with a boy waving from a window or a group of kids playing basketball. People in the street recognize them, call for them, say hello, etc. Safety workers' knowledge construction seems dependent on these brief but significant interactions. For long stretches of time, nothing seem to happen during their strolls through the city, and to make use of this time safety workers talk with the adults and youth they met: a librarian, a doorman, a hamburger salesman, a receptionist at the local swimming pool, a group of kids outside a school, or a newsstand employee. They pick up knowledge about youth and 'where the action is' (or will be) in a sort of mix between small talk and workrelated talk. In our 'go-alongs', we understood that they saw this personal knowledge as background for their interactions with young men in the street:

We-two 'yellow jackets' and two researchers-are now getting closer to a group of immigrant boys, sitting and standing around a car on a parking lot and along a low railing, not far from a school. You can tell that they see us coming and that the guards see them. One of the guards says to the other one, 
in a low voice and without turning his face to him, so that the kids will not notice that he is speaking: 'are there any celebrities?' The other guard responds in a similar fashion: 'No, it's a mix I think...' (fieldnotes)

By asking his colleague in a discreet way, and by using the word 'celebrities', the security guard is underlining both the value of knowing the young men's identities in the street and the value of not being perceived as ignorant. Had he asked more openly and with a normal voice, he would have risked being seen as lacking knowledge.

It took considerable communication for the safety workers to get glimpses of young people's actions and locations. Shop staff often call the blue jackets on their cell phones; security guards call the police and the pub doormen; red jackets call each other during their fieldwork; and all safety workers recognize each other in the street, talk in formal and informal meetings, and exchange information. In all this activity, an interest in ethnic minorities is implicated, because the young people hanging around downtown Landskrona often have immigrant backgrounds, like the boys in the above cited fieldnote. No interest in ethnicity was mentioned in the project's official documents; nevertheless, the more or less unspoken circumstances made ethnicity relevant. Boys with a Swedish background, mostly hanging around other places (for instance, involved in organized sports and leisure activities), were not targeted for policing to the same extent. Even though local officials pointed out that some areas in the relatively affluent suburbs were momentarily troublesome, the safety activities "never reached the same level" as in the city center, one official said. When asked whether this meant that more 'safety work' was directed towards immigrants than other groups, the official said "yes, as long as they are young", because the people present in potentially crime-generating contexts in downtown Landskrona are mainly youths. This topic was also touched upon during our go-alongs:

As we wander through a schoolyard, a blue jacket estimates that the proportional mixture of kids in "their" streets was $80-20$; i.e., $80 \%$ youth with immigrant backgrounds, $20 \%$ with Swedish backgrounds. "Most are immigrants", the blue jacket says (he also has an immigrant background), "but they don't divide themselves internally as clearly as in Malmö (a nearby, bigger city): Albanians in one group, Arabs in another, etc." Immigrant youth "hang out together in Landskrona", he says. As we pass a soccer field outside a school, the blue jacket makes a gesture towards a group of boys playing, with whom we had talked before (more have joined the group now), saying "there's a Kosovo-Albanian and a Pole and an Iraqi; they don't care about it, like they would in Malmö; here it doesn't matter where you come from; don't you agree, Arta?" Arta, another blue jacket behind us, nods. Later on, they both talk about the fact that they personally know many of these kids' families; for instance, their parents and older siblings. That makes it easier to know whom to call if the boys in the street do not behave. (fieldnotes)

The above excerpt shows a situation where it did not become too sensitive to talk in terms of ethnicities. Tolerance and peaceful interactions were the main points, not disturbances, conflicts, or crime. Nevertheless, it was clear that the knowledge construction within this safety work had focused in on some inhabitants of Landskrona more than others, and that safety workers made use of their own ethnically-based contacts to gather information for their job.

\subsection{Subtle Resources in Chatting}

Talking with people in the streets serves the dual purposes of constructing knowledge and providing safety. For instance, a quite extensive discussion with a shop assistant about shoplifters or thieves and exchanging words with a moped rider in a crossing is not about surveillance, one of the red jackets told us, but about 'keeping it (the city center) calm'. 'We have no authority', one of the blue jackets said, 'our weapon is to talk'. 'Sure, one might need to call the police sometimes', he added, referring to troublesome young men that had delivered threats, "but first and foremost, we try to talk them out of it'.

During our fieldwork, it became clear that these talks were aimed at establishing relationships with youths hanging around downtown Landskrona, typically immigrant youths. The fieldnotes above, in which two security guards approached a group of boys with immigrant backgrounds outside a school one night, continues like this:

The boys greet the guards, and the guards get closer and start talking with them. One boy is especially interested, shakes hands with one of the guards, and talks with him for quite a long time. It turns out that he is a former trainee at the youth club, Nova, who knows the guard from that period (the club is situated within the guards' patrol area). Another of the boys also joins the talk and wants to shake hands too; he wants to 'say hello to the guards', he says. He exchanges glances with us, as if to underline that being a guard is a little exciting. Most of the boys, however, remain standing or sitting as they were before, although they take notice of the guards and observe them while talking with each other. (fieldnotes) 
Safety workers see this exchange as a preventive measure; to start talking with youths hanging around downtown Landskrona at night, before any trouble emerges. They argue that relationships established in and through these talks may have a moderating effect if a conflict would arise, either that night or on another occasion. Also, they present themselves in a downplayed, quasi-informal manner. They would probably have made much more of a stiff, police-like impression if the guards had passed the boys without a word. The fact that they spend time to talk with the boys indicates that the youths in the street are a central concern in their work.

In this context there is a fine line between small talk and corrective activities. There was no doubt that, no matter how much they talked with guards and other patrollers, the youths did not regard safety workers as equals or vice versa. Safety workers embedded moral reminders and orders into their small talk, for instance by discreetly, in passing, telling a boy sitting on a car to get down. One guard told us about the importance of discretion in these cases, since one does not want the other to lose face in front of friends. Therefore, corrections should be conveyed subtly and in private. This control style goes hand in hand with the behavior of staff at the youth club, Nova; there, staff separate kids that must be corrected from the rest of the group to avoid provocation. The difference is that safety workers do this in the street, without a separate room or other type of 'shield' (Goffman, 1963), which means that the way they talk must be fashioned to form a 'separate' communication.

Ethnicities were sometimes employed in this corrective talk, for example:

We are talking with some blue jackets outside Madde's Café at night when a boy throws a bike in the street; it is done as a protest or provocation, it seems, in response to something another youngster close to him must have said or done. Maybe they are going to start a fight? A lot of people around us look at him, as if expecting the boy to start doing worse things. One of the blue jackets goes over and talks with him. After a while, the boy takes his bike and disappears. The blue jacket returns and says that he 'threatened' to speak with the boy's dad about the scene he was making here, if he did not stop. He knows who the boy was and his father. The blue jacket adds that they are not supposed to 'threaten to tell parents', but, when they can (when they are able to identify the boys in question), they typically at least mention the parents, because it often works. The youths do not want their parents to know what they are up to. We later learn that the blue jacket and the boy that threw the bike had the same (non-Swedish) ethnic background, and that the corrective speech was spoken in their language. (fieldnotes)
Here, the safety workers' knowledge of the youth and their use of talk as a social control mechanism are interconnected. The blue jacket saw the boy throwing his bike as the potential beginning of an escalating argument that might lead to a fight with someone nearby, and he employed his knowledge about the youth by talking to him on the spot. The episode took place in front of an audience, but the boy did not lose face. The blue jacket did not shout at the boy, which would tempt the boy to shout back or take action; instead, he got close to the boy and reminded him discreetly (looking him in the eyes) that he knew his father. The fact that we were told about this method later did not interfere with its application; rather, the account seemed to be embedded into the practice. The blue jacket did not disclose to the boy in question, or to anyone in the street, that he 'threatened to tell the parents'; he only told us.

Ethnomethodology suggests that the ethnographer pays attention to the way that a 'natural fact' is interactionally produced and sustained (Pollner \& Emerson, 2001, 2010, p. 125). Therefore, we ask ourselves how ethnicity, as a 'natural fact', is taken for granted, identified with, and shared between the blue jacket and the boy in question, and how this is done without drawing too much attention in the public place. First, we should note that the above episode demonstrates why the safety work organizers in Landskrona emphasize the importance of employing patrollers that comprised a non-Swedish, ethnic mixture. Given the ethnic divisions in the city center, the probability that a blue jacket would personally know a potentially troublesome boy in the street (and being able to deliver corrections without causing him to lose face) turns out to be much higher when they shared an ethnic identification. People tend to know each other within ethnic categories in the small city of Landskrona. This policing-facilitating circumstance seems to be seen as an advantage; the ethnic minorities in downtown Landskrona are easier to control with the help of enrolled representatives of (some of) these minorities. However, we could also see it from another viewpoint; when the controlling staff is filled with such representatives, the youth that belongs to these ethnic minorities probably receives increased policing. For instance, a blue jacket praised a colleague for being an excellent safety worker, because he "knows the languages", "knows the immigrant mentality", and therefore, he could "speak with the parents" (cf. Löfstrand, 2013, p. 237); the relevant parents were quickly and implicitly defined as adults with immigrant backgrounds, and the safety worker's similar background was recognized as preventive capital. Thus, ethnic identities and ethnically defined interests were crafted in and through policing practices, because the situated safety work included a continuous accomplishment of ethnicity. And belonging to an ethnic minority in the first place came to mean that you were targeted for plural policing.

Second, these inbuilt conditions for and execution 
of inter-ethnic control were subtle and implicit. The ethnic mix among patrollers was not described in terms of more efficient control, but in terms of representation, communication, and identification (e.g., a brochure stated "they know many languages, so they can reach many"). The youth in downtown Landskrona should not feel that safety workers were 'outsiders'. Cases like the one above, where safety is produced with the help of shared ethnicity, are not described in official documents or presentations; therefore, "doing" ethnicity remains quite silent. Also the fact that schools in the central-eastern part of the city are focused more on safety work than the other schools (as officials confirmed) implicates certain ethnicities, because everybody knows that those schools have relatively more students of ethnic minority backgrounds.

\subsection{Subtle Concerns in Patrolling and Youth Activation}

Apart from knowledge construction and talks, visibility through expressive patrolling is an established method among the safety workers. By merely displaying themselves in downtown Landskrona, safety workers are convinced that they sustain other people's composure and calmness. 'Our point is to show that we are there', one of the blue jackets said, 'that ensures that potentially troublesome youth do not dare to do anything.'

Visibility is evident in several ways. The blue jackets wear special blue clothes that are recognized by people in Landskrona, and the security guards are similarly easy to identify (first they wore yellow jackets, later, they wore dark blue uniforms). The social service fieldworkers wear red jackets, and they are also quite well known, although not as well-known as the blue jackets. The blue jackets drive a quite conspicuous car, with the text 'Blue Jackets-For Your Safety' printed on the sides, and they sometimes receive a lot of publicity in the local press. Above all, safety workers patrol almost all the time; anyone doing errands in the city center would sooner or later come across them. The fact that safety work was mainly associated with patrolling was firmly established, to the extent that youth in Landskrona sometimes made fun of it:

We walk towards Grenden, a restaurant, and we pass a couple of boys and girls standing in a little parking lot along the street. They see the guards approaching, and one says, in a joking manner, 'couldn't we swap jobs?' Then he pretends to be a guard. He straightens himself up, takes a few steps in a slow pace, and pushes his chest out. Another guy joins in; he comes up on bike, quite close to us, and says the same thing, 'couldn't we swap jobs?' One of the guards starts joking too, and offers the boy on the bike his badge, normally fastened with Velcro on the guards' shirts, but the boy said 'no thanks'. (fieldnotes)
When these kids made fun of the guards (and the guards made fun of themselves), they imitated the most emblematic features of the guards: their style of walking and their badges. Visibility is central in defining this kind of safety work; to wear a badge and to patrol in a particular style are clear ways to display oneself in

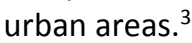

As we have already shown, it would be a simplification to argue that people of one ethnicity tried to control those of another: the fact that the blue jackets consisted of an ethnic mixture complicates that picture. However, it would not be a simplification to argue that the objects of control consist mainly of young men with immigrant backgrounds, because these inhabitants and city users are very prevalent in the area being watched. In our conversations with youth of various ethnic identities, it was also evident that other young people 'drove around' or 'took a walk' to check things out, particularly at nights and on weekends. For example, two ninth-graders said 'Our friends (or siblings) drive us around to check things out', 'we look around to see what's up', and 'nobody wants to miss anything'. This was part of the young people's established activities: to move around downtown Landskrona without any particular mission, except to gather information about people's behavior and find out 'where the action is'. This activity provides safety in numbers and demonstrates adolescent independence (McAra \& McVie, 2005, p. 6). Against this background, one could say that safety workers merely formalize and strengthen a way to use the urban area that already exists among city youth and, not least, immigrant youth.

Thus, ethnicity was implicated spatially. The acts of living and walking around in the designated area signified, to patrolling safety workers, that a person belongs to a category that deeply concerns safety workers. Moreover, because this area in Landskrona is not considered completely "Swedish" (when it came to housing), all non-Swedish ethnicities are lumped together and problematized. Indirectly, an encounter with safety workers meant that a non-Swedish ethnicity was interactionally underlined and loaded with potential

\footnotetext{
${ }^{3}$ During our 'go-alongs', we noticed that this 'visibility work' could be quite exhausting. After a couple of hours of displaying themselves as safety producers, the patrollers tended to withdraw for a while, for instance, to a café or a bench, to relax. However, any withdrawal from patrol was a bit controversial, because this visibility served both to create conditions for executing control and to turn safety workers into objects of control. For instance, people might complain (in letters to the press or when engaging in small talk) that blue jackets too often drove their car instead of walking; in response, blue jackets sighed over the fact that people claimed they should be on the move all the time, not resting for a single moment.
} 
crime-and/or-victim identities. This observation does not refute the argument that those encounters could be quite welcome, given the crime rate within the 'critical area'; nevertheless, a particular type of social production was carried out.

In addition to patrolling as a safety-producing method, we found youth motivation projects. Thus, alongside the project 'A Safe Downtown', there were several examples of municipal efforts to occupy the Landskrona youth. For example, the 'Open Square' in nearby Häljarp, the youth club Nova, and 'Open Dammhag' were all events that offered a range of leisure activities, sports, games, competitions, cultural events, etc. aimed to attract teenagers and stimulate them to create new social ties. The link between non-Swedish youth with 'nothing to do' and criminality or gang activities were also recurrent themes in newspaper articles, like the article on the basketball club called 'Bosna basket'. ${ }^{4}$

Safety workers sometimes apply this approach. As they construct knowledge about youth, talk to them, correct them, and demonstrate their downtown presence, they also encourage certain activities. They might, for instance, try to encourage boys and girls to visit a youth club by referring to what is happening there right now, or what is going to happen quite soon; they might also promote playing football or other sports by becoming participants. When passing a football game involving some immigrant boys outside a school, a blue jacket that shared ethnicity with some of the players may playfully throw himself into the game, shout some cheers, and pass the ball to some other player; then, he returns to his normal duties. In a similar manner, the security guards might joke or dance a few steps in the street with an intensely chatting pub guest, as if to strengthen a morally preferred activity (dancing, partying), and deflect interpersonal conflicts.

The ideal outcome seems to be to redirect potentially troublesome youth, not only by controlling behavior, but by sculpting it. Fights or disputes could be exchanged for more constructive (and conventional) activities, such as sports, games, music, dance etc. The annual report of the municipal Unit for Preventive Work stated that 'problems and restlessness in pedestrian areas' have been responded to by 'regular meetings [with youth] at the youth club, Nova' and by 'establishing re-

\footnotetext{
4 The preamble to this article (Landskronaposten 2006-03-14) read 'What is being done about juvenile crime in Landskrona?' One part of a solution to juvenile crime, discussed in the article, was formulated in terms of 'integration'. One might expect that integration would concern both immigrants and Swedes, but the article's focus was on immigrant boys. The journalist wrote, more or less implicitly, about keeping immigrant kids off the street. 'Bosna basket' seemed to provide an example of how this could be done; i.e., immigrant kids are kept out of trouble by playing basketball.
}

lations' with youth. Thus, the unit was said to have promoted 'activities other than vandalizing or destroying' (Versamhetsberättelse, Enheten för förebyggande arbete, 2006, p. 2, our translation).

The formal title for blue jackets is somewhat telling in this respect; in employment documents they are not called crime preventers, but 'recreation assistants'. This title reflects a distinct meaning of their work and work area. Metaphorically, downtown Landskrona becomes a sort of open youth recreation center, and the blue jackets its staff. Thus, their roles of redirecting behavior and motivating youth, rather than solely preventing crime and producing 'safety', do not seem out of place.

Nevertheless, among the ethnically-mixed youth we met, the lack of activities sometimes seems to be significant. Landskrona had become 'so boring', some ninth-graders told us, and the youth club Nova was not appreciated by all. Two minor shopping malls were empty; their shops were considered dull. The blue jackets complained about the same things. Our patrols in downtown Landskrona could inspire gloomy reflections on empty stores and the lack of local investments. Despite all the municipal projects, there remained an enduring flavor of lifelessness. An official told us that many Swedish middle class youngsters in the more affluent suburbs were engaged in organizations for sports, culture, or other leisure activities; but youth in the central-eastern part of the city were more freely "wandering around in the center". This more or less implicit ethnic division explained the motivation efforts.

In a survey of 70 pupils, ages 17 and 18, at Gullstrandsskolan, around $60 \%$ said that they lacked leisure activity centers, like youth recreation centers, cafés, and discos in Landskrona, and only $16 \%$ said that they were able to influence their own leisure time (Said et al., 2006). In our interviews, the youth talked a lot about the need for cultural activities in downtown Landskrona (not just sports, but music and other performances); however, social workers said that those types of activities were not always popular among older Swedes, and therefore, they were not always carried out; thus, the boys started making trouble instead.

Consequently, it was a specific version of 'activity' that the safety workers wanted; they did not want any activity for youth (e.g., fighting, disturbing the peace, or vandalizing are also activities), but 'motivated' activity (e.g., dancing, playing sports, watching performances, etc., that is motivated in conventional terms). When we met adults in Landskrona that were afraid of being in the city center at night, they associated their emotions with a particular image: an 'empty' center; that is, empty, apart from boys hanging around in 'gangs'. Between the lines, and with the contemporary media coverage in mind, they seemed to refer to youth with immigrant backgrounds that had nothing conventional or morally legitimate to do. 


\section{Conclusion}

In this article, we analyzed a case of community safety work and its implementation in Landskrona, a small town in southern Sweden, where municipal officials launched a crime prevention project. The project did not formally address ethnic minorities but focused on a 'critical area' in the city center. However, this spatially demarcated design provided a crucial condition for the continuous reproduction of ethnicities in "soft" policing. Safety workers were tied to a particular urban zone with a large proportion of individuals that had immigrant backgrounds. Subtle ethnic concerns and ethnic resources were embedded in their activities, including intelligence gathering, the use of 'talks' in the streets, patrolling, and motivations, through which they became more or less silently orientated to local minorities. Safety workers searched downtown Landskrona for 'where the action is' (Goffman, 1967, p. 149; Peterson, 2008, pp. 114-115) but they also saw the entire downtown as a place of 'action'. This spatially-based effort aimed to control an area that contains a particularly large number of immigrant families, who reside there and use the streets ( $42 \%$ have a 'foreign background'). The control effort reinforced an image of norm violation as typically 'un-Swedish'.

Generally, plural policing constitutes an altered environment for maintaining order and security. When a network of providers replaces a single provider, it seems logical that concepts of regulation and accountability must change, although it is far from clear how (Loader, 2000). An important aspect of the scientific interest in plural policing appears to be an aspiration to gain an overall picture of this new landscape of control, to be able to understand and evaluate it. Before Loader (2000, p. 323) tries to 'tease out' implications for the democratic legitimacy of plural policing, he begins by documenting the network of providers that constitute the policing field locally, nationally, and transnationally.' We found an equivalent aspiration in the municipal organizer, who wished to get an overall picture of all the safety efforts in Landskrona. She and her colleagues sometimes seemed a bit confused by the same fragmentation and diversification that scholars currently wrestle with.

Our point is that there was a device in the 'A Safe Downtown' project and its associated activities that organized all safety workers' efforts, namely the downtown area and its ethnic implications. In interviews and in small talk with the organizer, we found no particular ideological or methodological bias, but instead there was a broad interest in any concrete crime preventive strategy that might work. If we consider Landskrona's safety work as a form of power without a center, or a governmentality, we might say that the fear of crime and crime-related conduct instigated by Landskrona's youth was regarded as a technical matter-a matter of creating a 'safe downtown'-that could become a 'governmental' directive (Rose \& Miller,2008, p. 15). The unquestionable axiom was the troublesome city center; all concern revolved around this 'critical area'. As we have shown, this axiom implied ethnicities, or more specifically, it implied that ethnic minorities were the target of safety work, and simultaneously a resource for carrying it out. Without explicitly stating it, this means that the project both responded to and reflected the picture depicted by local journalists of Landskrona's crime and security problems. To seek to govern is to subscribe to a specific 'problematizing activity', Rose and Miller (2008, p. 61) argues; here, we may say that it is a matter of negotiating such an activity.

Many studies of stigmatized neighborhoods or urban marginality are dressed in much more dramatic terms than our study. However, there are certainly similarities; for example, Landskrona could be seen as a "depressed" district in southern Sweden (relative to nearby Helsingborg, Lund, and Malmö), similar to the description that Wacquant $(2008,2013$, p. 4) gives of La Courneuve outside Paris. Also in Landskrona there seem to be "a feeling of insecurity rooted in the ecology and demography of the neighborhood and fuelled by petty youth delinquency" (Wacquant, 2008, 2013, p. 205). Nevertheless, the policing activity in Landskrona is not identical to the policing of "symbolically spoiled zones" or a former "dumping ground" for the lower fractions of the working class (Wacquant, 2008, 2013, pp. 197, 202). The targets of the safety work in Landskrona are not as marginal, the streets are not as shabby, the inhabitants' future prospects are not as limited as those described by Wacquant; his terminology is too radical to apply to Landskrona. Rather, we argue that ethnicizations of a policing project and its urban space can be found in subtle, implicit forms within more affluent settings that extend beyond the banlieus of Paris or the "hyper-ghettos" of the U.S. This point is demonstrated by our ethnographic data and our eye for the possibility that ethnicities may come to constitute both the target of policing and a resource for the policing process. In any setting that defines safety and fear of crime in spatial or territorial terms, ethnicities may be implicated along these lines, given that the urban space continues to be ethnically segregated and that crime prevention continues to be situationally conceived. Since both these trends are salient in today's society, the results of our study of safety work with an ethnic slant are probably transferrable to many settings.

In future studies, it would be interesting to investigate further whether and how other spatially-defined versions of plural policing might include diversified efforts that "do" ethnicities, particularly because the socalled 'situational' crime prevention methods have become much more popular than 'social' methods (e.g., improving schools and other socializing institutions, 
Sahlin, 2000). If policing organizers understand crime spatially and locally, and if ethnic segregation continues to characterize housing patterns, we might expect to see more examples of security devices that are implicitly underpinned by ethnic concerns and resources. 'Doing' ethnicity may turn into an implicit organizing device, despite an otherwise diverse, multi-centered, or sporadic organization, as if it knitting together a broad set of technologies within an otherwise relatively mixed, varied effort to 'conduct conduct', or establish a 'governmentality' (Rose \& Miller, 2008). Future studies could also investigate how safety work might be organized in other ways, for instance translocally, institutionally, or with alternative demarcations, which may, perhaps, implicitly or explicitly undo ethnicity.

\section{Acknowledgements}

We are very grateful for the helpful comments contributed by all members of the plural policing network in Sweden and for the comments from four anonymous reviewers.

\section{Conflict of Interests}

The authors declare no conflict of interests.

\section{References}

Becker, H. S. (1998). Tricks of the Trade. How to think about your research while you are doing it. Chicago: University of Chicago Press.

Billig, M. (1995). Banal Nationalism. London: SAGE.

Bosworth, M. (2004). Theorizing Race and Imprisonment. Towards a New Penality, Critical Criminology, 12(2), 221-242.

Brubaker, R., Loveman, M., \& Stamatov, P. (2004). Ethnicity as Cognition. Theory and Society, 33, 31-64.

Burgess, E. W. (1967). The Growth of the City. An Introduction to a Research Project. In R. E. Park, E. Burgess, W. Ernest \& R. D. McKenzie (Eds.), The City. Chicago: University of Chicago Press.

Centrum-och Österlyftet. Strategisk stadsdelsplan (2007). Landskrona kommun: Strategikontoret.

Choongh, S. (1998). Policing as Social Discipline. British Journal of Criminology, 38(4), 623-634.

Crawford, A. (1997). The Local Governance of Crime. Appeals to Partnerships and Community. Oxford: Claredon.

Diesen, C. (2005). Negativ särbehandling i rättskedjans alla led. In SOU 2006: 30. Är rättvisan rättvis? Stockholm: Statens offentliga utredningar.

Ekman, G. (1999). Från text till batong: om poliser, busar och svennar. Stockholm: The Economic Research Institute at Stockholm School of Economics.

Emerson, R. M., Fretz, R. I., \& Shaw, L. L. (1995). Writing Ethnographic Fieldnotes. Chicago: University of
Chicago Press.

Eriksen, T. H. (2004). Rötter och fötter. Identitet $i$ en föränderlig tid. Nora: Nya Doxa.

Garfinkel, H. (1999). Studies in Ethnomethodology. Cambridge: Polity Press.

Goffman, E. (1963). Behavior in Public Places. New York: Free Press.

Goffman, E. (1967) 'Where the action is' in Interaction ritual. New York: Doubleday.

Granér, R. (2004). Patrullerande polisers yrkeskultur. Lund: School of Social Work, Lund University.

Hansen Löfstrand, C. (2013). När säkerhet blir en marknadsvara: etnisk mångfald som resurs och problem för bevakningsföretag. In A. Peterson \& $\mathrm{M}$. Åkerström (Eds.) Den sorterande ordningsmakten. Studier av etnicitet och polisiär kontroll. Lund: Bokbox.

Heritage, J. (1984). Garfinkel and Ethnomethodology. Cambridge: Polity Press.

Ilan, J. (2010). 'If you don't let us in, we'll get arrested'. Class-cultural dynamics in the provision of, and resistance to, youth justice work. Youth Justice, 10(1), 25-39.

Jones, T., \& Newburn, T. (Eds.) (2006). Plural Policing. A Comparative Perspective. London and New York: Routledge.

Kriminalunderrättelsetjänsten (2006). Polisområde nordvästra. Polismyndigheten i Skåne.

Kusenbach, M. (2003). Street Phenomenology: The GoAlong as Ethnographic Research Tool. Ethnography, 4(3), 455-485.

Lilly, J. R., Cullen, F. T., \& Ball, R. A. (2007). Criminological Theory. Context and Consequences. Thousand Oaks, London, New Delhi: SAGE.

Loader, I. (1997). Thinking Normatively About Private Security. Journal of Law and Society, 24(3), 377-394.

Loader, I. (2000). Plural Policing and Democratic Governance. Social \& Legal Studies, 9(3), 323-345.

McAra, L., \& McVie, S. (2005). The usual suspects? Street-life, young people and the police. Criminal Justice, 5(1), 5-36.

Moerman, M. (1974). Accomplishing Ethnicity. In R. Turner (Ed.), Ethnomethodology. Harmondsworth: Penguin.

Olsson, L. (2007). Alla som har råd flyttar ut från Landskrona centrum. Expressen. 2007-02-11.

Östlund, E. (2013). Polisens sökarljud. Etnicitet som urskiljningsfaktor i det operativa polisarbetet och hur den legitimeras. In A. Peterson \& M. Åkerström (Eds.) Den sorterande ordningsmakten. Studier av etnicitet och polisiär kontroll. Lund: Bokbox.

Peterson, A. (2008). Who "Owns" the Streets? Ritual Performances of Respect and Authority in Interactions between Young Men and Police Officers. Journal of Scandinavian Studies in Criminology and Crime Prevention, 9(2), 97-118.

Pettersson, T. (2005). Polisingripanden vid eget bruk av 
narkotika: särbehandlas personer med utländsk bakgrund? Kriminologiska institutionen, Stockholms universitet.

Polisen (2004). Polisens medborgarundersökning (2004). Nordvästra Skåne.

Pollner, M., \& Emerson, R. M. (2001). Ethnomethodology and Ethnography. In P. Atkinson, A. Coeffey, S. Delamont, J. Lofland \& L. Lofland (Eds.), Handbook of Ethnography. Los Angeles, London, New York, Singapore, Washington DC: SAGE.

Rose, N., \& Miller, P. (2008). Governing the Present. Administering Economic, Social and Personal Life. Cambridge: Polity.

Sahlin, I. (2000). Brottsprevention som begrepp och samhällsfenomen. Lund: Arkiv.

Said, K. B., Larsson, D., Xhemajli, A., \& Xhemajli, M. (2006) Idéprojekt för en värdefull fritid. Landskrona ungdomsforum. Programmet för fritidsarbete och fritidskultur. Lund: Lunds universitet.

Tonry, M. (1996). Ethnicity, Crime and Immigration. In M. Tonry (Ed.), Crime and Justice, Volume 21. Chicago: Chicago University Press.

Verksamhetsberättelse. Enheten för förebyggande arbete [Annual report. Crime Prevention Unit] (2006). Landskrona: Children and Youth Administration, The Municipality of Landskrona.

Wacquant, L. (2008/2013). Urban Outcasts. A Comparative Sociology of Advanced Marginality. Cambridge: Polity Press.

Wästerfors, D. (2006). Kamerans konsekvenser. En fallstudie av kameraövervakning mot bilbrott $i$ Landskrona. Lund: Network for Research in Criminology and Deviant Behaviour at Lund University.

\section{About the Authors}

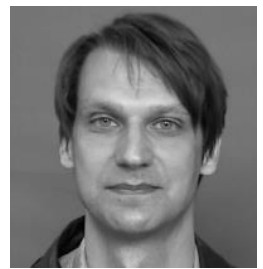

\section{Dr. David Wästerfors}

David Wästerfors is Associate Professor and Senior Lecturer at the Department of Sociology at Lund University, Sweden. He is currently working in an ethnographic project on school work for young criminals in residential treatment, and he has also done fieldwork among businessmen, urban crime preventers, and children with disabilities. He is often using interactionist, constructionist and ethnomethodological perspectives to analyze ethnographic data.

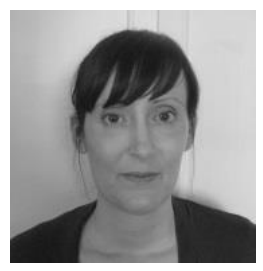

\section{Dr. Veronika Burcar}

Veronika Burcar is a university lecturer at the Department of Sociology, Lund University. Burcar is teaching sociology, social psychology and criminology and her research interests revolve mainly around young people's experiences of violence and victimization, fear of crime, safety issues and mediation between victims and offenders. Currently she is working on a project on young criminals as victims as well a project concerning young people's position in competing for public space. 